\title{
The Pleasures of Recognition : Two Recent Finnish Appropriations of Romeo and Juliet
}

\section{Keinänen, Nely}

2019-04-03

Keinänen , N 2019 , ' The Pleasures of Recognition : Two Recent Finnish Appropriations of Romeo and Juliet ' , Shakespeare , vol. 15 , no. 2 , pp. 176-187 . https://doi.org/10.1080/17450918.2018.1531914

http://hdl.handle.net/10138/314609

https://doi.org/10.1080/17450918.2018.1531914

unspecified

acceptedVersion

Downloaded from Helda, University of Helsinki institutional repository.

This is an electronic reprint of the original article.

This reprint may differ from the original in pagination and typographic detail.

Please cite the original version. 


\title{
The Pleasures of Recognition: Two Recent Finnish Appropriations of Romeo and Juliet
}

\author{
Nely Keinänen
}

Department of Languages, English philology, University of Helsinki, Helsinki, Finland

P.O. Box 24 (Unioninkatu 40)

FI-00014 University of Helsinki, Finland

nely.keinanen@helsinki.fi

Nely Keinänen studies the translation and reception of Shakespeare in Finland, and has published articles in Shakespeare, Multicultural Shakespeare and other journals.She is the coeditor of Authority of Expression in Early Modern England (Newcastle upon Tyne: Cambridge Scholars Publishing, 2009), with Maria Salenius. In Finnish, she has edited two collections of essays, one bringing together translators, directors, and actors to discuss Shakespeare in Finland, and another on early Finnish Shakespeares. She also reviews Finnish Shakespeare performances for ReviewingShakespeare.com. In her spare time, Keinänen translates contemporary Finnish drama into English, including three Shakespeare spin-offs, two of which are discussed here.

\section{The Pleasures of Recognition: Two Recent Finnish Appropriations of Romeo and Juliet}

This essay examines two Finnish appropriations of Shakespeare's Romeo and Juliet: Jari Juutinen's monologue Juliet, Juliet! (2007) and Lauri Sipari and Liisa Urpelainen's play for two characters, Romeo vs. Juliet (2014). Both plays rewrite the story, Juutinen by layering it onto a real life event, where a Finnish woman murdered her husband and children after she got into debt; and Sipari and Urpelainen by imagining what might have happened had Romeo and Juliet made it to Mantua and gotten married. Both plays are also interested in the cultural resonances of Shakespeare's original language, juxtaposing textual allusions to (Finnish translations of) Shakespeare's original with modern text, sometimes for deliberately jarring, but also comic effects. Both plays also question the modern day implications of star-crossed love and tragic catharsis, and their use in 
contemporary Finnish theater. The essay adds to our knowledge of Shakespearean afterlives, showing how recent Finnish writers have responded to this most canonical of plays.

Keywords: William Shakespeare; spin-off; rewriting; Jari Juutinen; Lauri Sipari, Liisa Urpelainen

In her essay "Recognizing Shakespeare, Rethinking Fidelity: A Rhetoric and Ethics of Appropriation," Christy Desmet argues "for a dialogic concept of appropriation that is based on the act of recognizing Shakespeare in another writer or text" (41). Her essay analyzes several types of appropriations, including direct quotation, recycling, and even accidental. Direct quotation, as she notes, can easily become "epistemologically knotting and ethically fraught," for "ventriloquism shades suspiciously into impersonation, speaking for someone else into satire, slander or verbal hijacking" (47). In her analysis of the ways Charles Marowitz "recycles" Shakespeare by rearranging his texts, Desmet notes that he "depends on the audience's recognition of Shakespearefamiliarity with plots, sayings, characters gleaned from any number of sources-in order for his plays to make sense and achieve their desired effect" (Desmet 50). Appropriations feature tensions between fidelity and infidelity, between the familiar and the new. ${ }^{1}$ Although audiences differ in their previous knowledge of Shakespeare, it seems that at least in connection with the most famous plays, an audience can “recognize Shakespeare in the 'cultural smear' of its collective unconscious" (Desmet

\footnotetext{
${ }^{1}$ A great deal has been written on Shakespeare adaptation and appropriation. One of the best
} recent collections is Huang and Rivlin, but see also Levenson, Orkin and Scott-Douglass. The two best theoretical introductions to adaptation and appropriation continue to be Sanders and Hutcheon. 
50), a point that authors no doubt consider when they decide to rewrite Shakespeare.

In this essay, I shall discuss the uses of Shakespeare "sightings" in two recent Finnish adaptations of Romeo and Juliet: Jari Juutinen's Juliet, Juliet! (2007) and Lauri Sipari and Liisa Urpelainen's Romeo vs. Juliet (2014). ${ }^{2}$ Both rewritings ask us to imagine a world where Romeo and Juliet might have grown up, while acknowledging that their power as characters lies precisely in that they did not. A tragic monologue written in multiple voices, Juliet, Juliet! is based on the true story of a Finnish woman who killed her husband and children, and then herself, after falling into debt. Romeo vs. Juliet is a comic duologue in which Romeo and Juliet did not commit suicide, but married, had children, then divorced. Twenty-five years later, they meet on the platform of the Mantua railway station, waiting for delayed trains.

In these spin-offs, Shakespeare sightings function on multiple levels, both linguistic and thematic. Textually, allusions to Romeo and Juliet range from openly announced quotations to subtle interweavings of Shakespearean and modern language, often for comic effect, but also to heighten pathos. Both plays complicate audience recognition, Juutinen by adding imagery to well-known sequences, and both by reassigning text to different characters than in the original. In terms of theme, both spinoffs also comment on the ending of Shakespeare's tragedy, Juutinen by forcing his audience to think of the characters as real people, and Sipari/Urpelainen by creating a double layer working backwards and forwards in time, in the present tense towards a possible reconciliation at the train station, and in the past towards the moment they decide to live instead of die, with motifs from Shakespeare worked in throughout.

\footnotetext{
${ }^{2}$ I have translated both plays from Finnish into English. Juliet, Juliet! is available from Agency North and Romeo vs. Juliet from Nordic Drama Corner (Helsinki, Finland).
} 


\section{Textual Recognition: Finnish Theatrical Context}

Any discussion of "recognition" in foreign-language Shakespeare must begin by considering how recognition functions in a foreign theater context and language. Romeo and Juliet has a special place in the history of Finnish-language Shakespeare, as in 1881 it was the first full-length play performed in Finnish. ${ }^{3}$ Along with Hamlet, it continues to be one of the most performed Shakespeare plays in Finland, both having had approximately seventy professional productions since their first in the early 1880s, significantly more than other popular Shakespeare plays, e.g. The Tempest (49), Othello (32), and Macbeth (28). ${ }^{4}$ In terms of geographical reach, Romeo and Juliet has been produced multiple times at the Finnish National Theater ${ }^{5}$ in Helsinki, e.g. in 1887, 1904, 1918, 1946, 1961, 2002, 2018; at regional theaters, especially in Tampere and Turku; as well as at many smaller theaters throughout the country, including puppet theaters and children's theaters. It is also one of the plays which has inspired the most experimentation, including Otso Kautto's all-male production (Teatteri Pieni Suomi, 1992); Hilda Hellwig's bilingual production (Lilla Teatern, 1999), where the Montagues spoke Swedish and the Capulets Finnish; and even a film spin-off, 8 päivää ensi-iltaan

\footnotetext{
${ }^{3}$ The first productions of Shakespeare in Finland were done by groups of travelling players in Swedish, beginning in the 1760s. The first translation/adaptation into Finnish was Ruunulinna (1824), a domesticated version of Macbeth. The tercentenary of Shakespeare's birth in 1864 was marked by the translation and performance of scenes from Macbeth, followed in 1879 by Paavo Cajander's first translation into Finnish of a play, Hamlet (1879, not performed until 1884). For further details, see Aaltonen.

${ }^{4}$ According to statistics from the ILONA database maintained by TINFO (Theatre Info Finland).

${ }^{5}$ Known as the Finnish Theater from 1872-1902.
} 
[8 Days to the Premiere], directed by Perttu Leppä (2008), a romantic comedy where a theater company putting on Romeo and Juliet must find a new actress to play Juliet when the original falls off the balcony and hurts her leg. ${ }^{6}$

Given the status of Romeo and Juliet, it is not surprising that both spin-offs have generated theatrical interest both in Finland and abroad. Juliet, Juliet! premiered at a small, independent theater in the Finnish city of Pori in 2007, directed by Juutinen. It has been produced in Finland twice more, in 2008 at the Hämeenlinna City Theater (a major regional theater), directed by Helena Ryti; and again in 2012, at the Culture Factory in Helsinki, directed by Tommi Kainulainen. In 2010, the play was translated into French (Anne Cornette) and performed at the Theatre du Centaure in Luxemburg in the 2010-11 season, and this production was invited to perform at the Festival de Teatro de la Habana in 2011. The play has also been translated into Georgian (Ani Aladashvili and Dimitri Gogolashvili) and performed at the Liberty Theater in Tbilisi, Georgia, and the same company also produced an English-language version which played at the Tbilisi International Festival of Theater and will be performed at the United Solo Theater Festival in New York in the fall of 2018. Juutinen has directed all of these international productions. Romeo vs. Juliet was written for the Finnish actress MarjaLeena Kouki, and became part of the celebrations surrounding her $50^{\text {th }}$ anniversary as an actress. The play was produced in $2014-15$ by KOM Teatteri, directed by Laura Jäntti. KOM is located in Helsinki, but the play premiered as a guest production at the Vaasa City Theater and travelled all over Finland. It was revived with the same actors and director at another small Helsinki theater, Teatteri Jurkka, in 2017. The play has been translated into Estonian (Maimu Berg) and been produced twice in Estonia, at the

\footnotetext{
${ }^{6}$ For further information see Keinänen, "Suomalaisen" and "What's Global."
} 
Eesti Draamateater, Tallinn, directed by the group (opening in 2015 and remaining in the repertoire until 2018), and at the Karlova Teater in Tartu, directed by Ingo Normet (2015).

\section{Linguistic Recognition in (Translated) Shakespeare}

While in some countries and language groups, selected translations might achieve a kind of classic status and be memorable as such, at least in modern Finland there are multiple translations of many of the most-performed plays, and therefore individual lines may not be as "recognizable" as Shakespeare's English lines are to English-speaking audiences. Romeo and Juliet has been translated at least six times into Finnish, with some of those versions being reworkings of earlier translations. The first translation, and still the most recognizable, is by Paavo Cajander (1881). Romeo and Juliet's popularity in Finnish theater is reflected in the number of re-translations since then: Yrjö Jylhä (1955, close in parts to Cajander); Eeva-Liisa Manner (1961, a retranslation "based on Cajander"); Lauri Sipari (a new translation in 1980 without reference to Cajander, and another in 2002, the latter at the behest of a publishing company) $;^{7}$ Juha Siltanen (2002); and Marja-Liisa Mikkola (2006, another translation commissioned by a publishing company ${ }^{8}$ ).

Given this translation history, it is unlikely that Finnish audiences "recognize" Romeo and Juliet through specific well-known lines, ${ }^{9}$ but rather through references to

${ }^{7}$ Sipari's translations of Romeo and Juliet have been popular among directors, with productions in 1981, 1992, 1993, 1994, 1995, 1999, 2000 and 2003.

${ }^{8}$ In 2002-2013, the Finnish publishing company Werner Söderström Ltd (WSOY) embarked on a major project to re-translate the complete works of Shakespeare into modern Finnish. For information on the project and its reception in Finland, see Keinänen, "Canons."

${ }^{9}$ One of the oddest examples of a "well-known line" in Finnish is "To be or not to be." Most people quote a version of the line which does not appear as such in any of the published 
the characters and plot. Romeo's oxymorons on love, a textual allusion appearing in both spin-offs, provides a good example of the complexities involved in multitranslation transmission. For readers of Finnish, they also nicely demonstrate the contrasting translation styles of "original" Shakespeare that Juutinen and Sipari/Uutelainen selected for their appropriations. Juutinen uses Cajander's 1881 translation, which especially in this excerpt sounds old-fashioned, but also movingly poetic, even majestic (not captured in the back translation below):

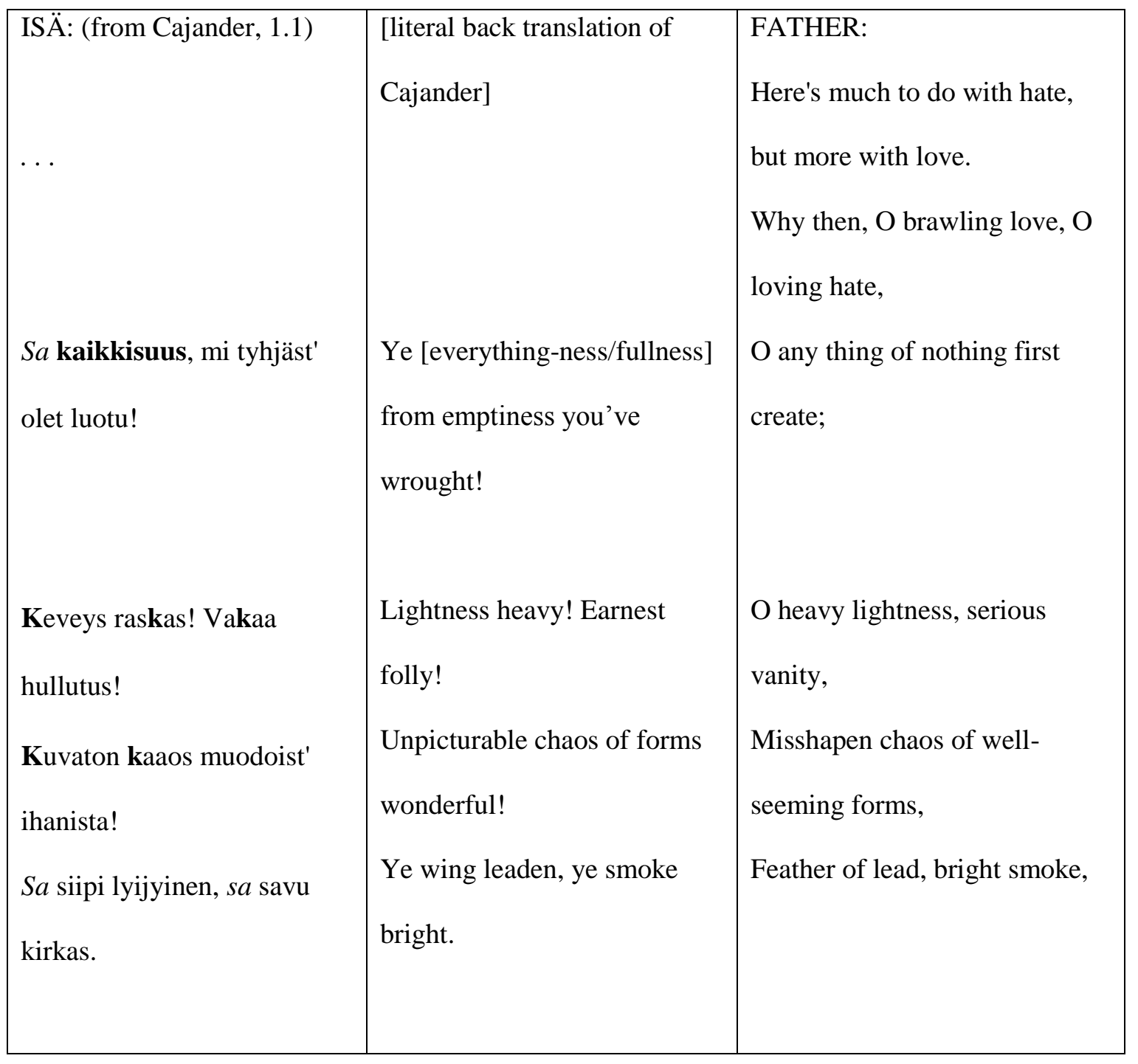

translations, a point which backs up Desmet's idea of a Shakespearean presence in a country's collective unconscious (50). For further information on Finnish versions of "To be," see Rissanen. 
Rythmically, Cajander attempts to reproduce iambic pentamenter (even though Finnish is a trochaic language), which can be seen in the repeated $s a$, a poetic way in the late $19^{\text {th }}$ century to say "you" and serving as an unaccented first syllable. Shakespeare's contrast of "any thing" and "nothing" is rendered with an unsusual Finnish word-derivation appearing in only a few works/writers of the late $19^{\text {th }}$ century, kaikkisuus, literally everything + ness, but perhaps better translated with "fullness" which is opposed to Cajander's “emptiness" [tyhjäst']. Cajander frequently makes effective use of poetic inversion, and especially the opening lines also have impressive $/ k /$ alliteration, established in kaikkisuus and then repeated in the following two lines. The hard alliteration is dramatically effective in Juutinen's spin-off, as here at the opening of Scene 1 (after a prologue discussed below), Juliet's father is angrily making fun of her romantic dreams, ripping pages from Shakespeare's Romeo and Juliet. In the father's mouth, these well-known lines of Shakespearean verse are satirized, an effect magnified by Juutinen's use of Cajander's translation.

Romeo vs Juliet opens with the same oxymorons, also announced as direct quotations from a Shakespeare original, but now in Sipari’s much more modern translation:

\begin{tabular}{l|l} 
ROMEO (Sipari translation) & (literal back translation) \\
Rakkaus- & Love- \\
sinä syntynyt et mistään, & You born from nothing, \\
raskas keveys, vakava turhuus, & heavy lightness, serious vanity, \\
muotokaaos, lyijyhöyhen, & shapechaos, leadfeather, \\
kirkas savu, kylmä tuli, & bright smoke, cold fire, \\
sairas terveys, uneton uni-- & sick health, sleepless sleep--
\end{tabular}

This Finnish is also richly poetic, but in a restrained way, with short lines (mainly 8 syllables), simple, modern vocabulary, normal word order, and short two-word units (or even created compounds). Some of the same words reappear from Cajander's translation, but the rhythm and feel are very different, though both are equally 
recognizable as "Shakespeare" in translation. ${ }^{10}$

Both of these excerpts are examples of announced, direct quotation from Shakespeare, and are no doubt the easiest for audiences to recognize. These particular quotations, placed either at the opening (Sipari/Urpelainen) or relatively close to it (Juutinen), also help to establish links to Shakespeare's Romeo and Juliet, announcing these plays as rewrites. But both plays use several other techniques in their Shakespeare textual sightings, including juxtaposition of Shakespearean and modern text, to which I turn next.

As a duologue, Romeo vs. Juliet most often draws attention to the two levels of its story by having one of the characters in the present suddenly switch to Shakespearean text spoken in the past, often leading to comic juxtapositions between naïve young love and the realities of life after marriage and children, accentuated by the style and register shifts. Scene 1 provides a good example: Romeo and Giulietta have run into each other at the railway station, and found out their trains are going to be delayed. Romeo is highly unsettled by this news, and starts pacing in anger, punching messages into his phone, which then also breaks. Giulietta gets exasperated and orders him to sit down. More in shock at her ordering him around than anything else, Romeo complies, comically morphing into his ardent younger, Renaissance self:

\section{ROMEO}

Giulietta. Are you telling me what to do?

${ }^{10}$ These stylistic contrasts between the translations used create some difficulties for a translator of foreign adaptations into English. When translating these two Finnish spin-offs into English, I chose to use Shakespeare's original, which means that the stylistic contrasts between Shakespeare quotations and modern text are larger in the English version of Romeo vs. Juliet than they are in the Finnish. Not all translators would make the same decision. 


\section{GIULIETTA}

No. Why would you think that?

ROMEO

/Her eyes-- / 11

GIULIETTA

Everyone is always saying I tell people what to do. It's not true.

ROMEO

1... Two of the fairest stars in all the heaven,

Having some business do entreat her eyes

To twinkle in their spheres till they return-- /

\section{GIULIETTA}

My suggestions are usually so good there is no better choice.

\section{ROMEO}

/What if her eyes were there, they in her head?

The brightness of her cheek would shame those stars

As daylight doth a lamp... /

\section{GIULIETTA}

For your information (11-12).

Romeo's ardent description of Juliet/Giulietta's beauty contrasts with Giulietta's matterof-fact explanations, showing that Romeo has lost little of his romantic self while Giulietta finds herself (once again) in the role of nagging, practical wife. This juxtaposition is by no means simple: while the play makes fun of the ardor of youth, it also recognizes that it contains a great deal of strength and beauty, and Giulietta's emotions are not nearly as controlled as she might prefer, as seen in the way she reapplies her lipstick as soon as Romeo goes to the bathroom.

In addition to these comic effects, and often in combination with them, sudden switches from the present to the past can also lead to moments of deep connection for the two characters, culminating in shared speeches drawn directly from Romeo and

\footnotetext{
${ }^{11}$ In the script, the authors use forward slashes to mark quotations of original verse lines from
} Shakespeare. 
Juliet. For example, in Scene 7, Romeo and Giulietta reminisce about how they met, the early happy years of their marriage as they had one daughter after another. Giulietta starts chiding Romeo for scratching, which he claims is a psychosomatic problem he has been cured of for the twenty-five years he has been free of her. This fight leads to an emotional turning point in the play, where they directly confront the family feud that forced them into a life in Mantua, away from their friends and family:

\section{ROMEO}

You hated your father... go ahead, hate yourself... nobody is more Capulet than you...

\section{GIULIETTA}

Montague... a true Montague, always stabbing you in the back...

Shit. Didn't we once agree that no matter what we said to each other, we would never say that?

\section{ROMEO}

We did. We held out pretty long. . . almost to the finish.

\section{GIULIETTA}

It's not even true. I'm not a Capulet.

\section{ROMEO}

No.

\section{GIULIETTA}

And you're you, not Montague.

At this point, Romeo switches back to his youthful self, in lines drawn from the balcony scene, while Giulietta remains firmly in the present:

\section{ROMEO}

/I know not how to tell thee who I am.../

GIULIETTA

Can you see the screen?

ROMEO

/My name, dear saint, is hateful to myself / Because it is an enemy to thee.../ GIULIETTA

(Picks up the menu)

We probably have time for dessert. 


\section{ROMEO}

/Had I it written, I would tear the word.../

\section{GIULIETTA}

They have the usual. Tiramisu, panna cotta, fruit salad...

\section{ROMEO}

/Call me but love, and I'll be new baptized. / Henceforth I never will be Romeo./

But then Giulietta turns into Juliet, picking up at "What's Montague? It is nor hand nor foot" and together they go through a Shakespearean sequence combining lines from 2.2 and 2.6, concluding with Juliet having the last words: "My bounty is as boundless as the sea, / My love as deep. The more I give to thee, / The more I have, for both are infinite" (37-39). Here the shift from comic juxtaposition to full quotation of the Shakespeare original effectively deepens the emotion, becoming the vehicle for expressing their old, and not completely forgotten, love; and the stylistic shift from prose to poetry also signals to the audience that we are now back in the poetic world of Shakespeare's version.

Juutinen similarly juxtaposes Shakespearean phrases and modern language to comic effect, particularly in the speech of teenage Raimo, ${ }^{12}$ though the effects are quite different from Romeo vs. Juliet. Interspersed in much of Raimo's monologue are very short quotations from or allusions to Shakespeare's language, often undercut by quick changes in rhythm and diction:

Shh! Guys shut it!

Guys look guys!

those

hands mouth eyes!

Those lips.

\footnotetext{
${ }^{12}$ Raimo is an ordinary Finnish male name, clearly a play on "Romeo."
} 
O heaven above

It is my love

Never forget

It's Juliet,

It's JULIET! (9)

Juutinen deftly parodies Shakespeare's more exalted verse by having Raimo stumble into ever-sillier rhymes as he stares at Juliet and struggles to find the courage to go over to her:

Oh look guys look, her eyes they shine like fire

Or like stars far away,

stars at play

in the milkyway (9).

Some of the quick shifts are very striking, capturing the rhythms of angst-filled youthful speech:

But I couldn't on the wings of love fly by

Like voluntarily (10).

At other points, however, Shakespearean quotation (in italics below) adds a sonorous beauty that is allowed to stand unchallenged, at least for the duration of a line or two:

And what if I said, if I swore and swore

If I vowed by yonder blessed moon,

That tips with silver all these fruit-tree tops.

Of course! You're right.

I will never ever ever swear by the moon

The inconstant moon (11).

Especially in connection with Raimo, these Shakespearean quotations, echoes and comic additions weave an intertextual fabric mainly poking fun at young love, while 
recognizing the longing to find the kind of love immortalized in Romeo and Juliet and thus setting up the tragedy.

Above we have examined examples of direct quotation on their own or juxtaposed with modern speech, but Juutinen in particular is also a master at using subtle Shakespearen textual allusions to heighten pathos. The best example of this comes in parallel moments in the prologue and towards the end of the play, using repeated imagery of skylarks and dawn drawn from the well-known abaude scene (3.5). In the real life event the play depicts, the woman seems to have waited an hour between the time she killed her husband and children and herself, and Juliet tells us her story during that hour:

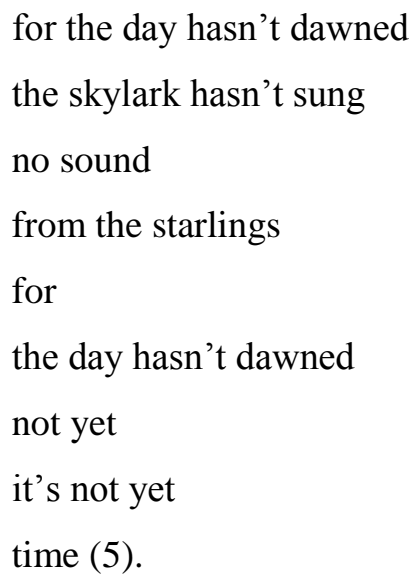

It is perhaps unlikely that anyone but a devoted Shakespeare scholar would hear these echoes, but Juutinen must think they are at least somewhat recognizable for he returns to this imagery towards the end of the play. As Juliet begins to sink deeper into the desperation of myriad unpaid bills, she speaks words recognizably Shakespearean:

It's not yet near day, no, it was the nightingale, and not the lark, That pierced the fearful hollow of your ear (23).

Other Shakespearean phrases are repeated, such as "yon grey," "morning's eye," the lark "whose notes do beat / The vaulty heaven so high above our heads" (24). Playing 
with audience recognition still further, Juutinen does not limit himself to the imagery available in Romeo and Juliet, but adds the image of a boar:

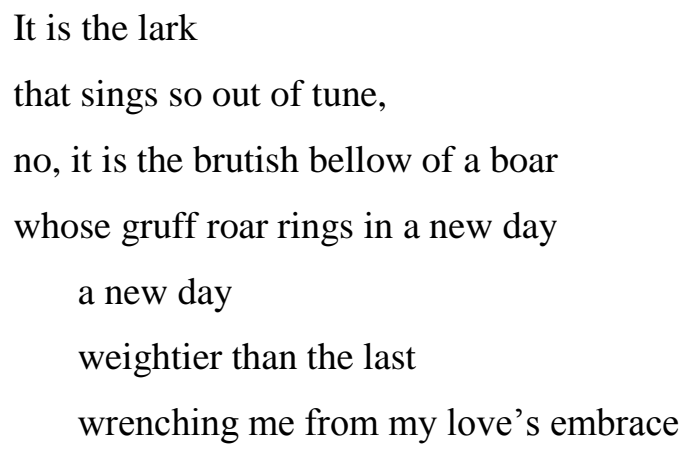

And still the sky brightens, merciless (24).

Moments from the end of the play contain similarly subtle Shakespeare textual allusions. Juliet opens a curtain, speaks the Shakespearean line: "Then window, let day in, and let life out!" before picking up her shotgun and loading both barrels. The scene ends with Juliet thinking about “One last kiss," echoing Romeo's request for "one kiss."

As we saw in the previous example, a further way of playing with audience recognition is to add unfamiliar imagery to familiar. Another is to reassign Shakespearean speeches to different characters. Again, these points are rather subtle, as most viewers probably don't have such complete knowledge of the play that they would recognize who actually says what in the source text. An illustrative example from Juliet, Juliet! comes from the Father's speech at Juliet's wedding (scene 5), which brings in lines of the Nurse:

Just yesterday I suddenly remembered when my daughter Juliet, she must have been about three years old, just weaned from her mother's boob, was toddling around, sorta like she still does sometimes, around and around, toddling, have you ever noticed how she still does that, yeah well she was trying to walk and she hit her head on the edge of a table and fell down on her face right in front of 
me and I said "now, little girl, you fall face down in front of a man, when you get a little older, you'll learn to fall backward, will you not, Jule?" and Juliet threw off her tears and said, "yeah.” And I guess that's what's happening now.

The effect here (as it can also be with Shakespeare's Nurse), is to make the character appear crude, in Juutinen's play even more so.

A similar example of line-mixing can be found in Romeo vs. Juliet, scene 4, where Giulietta/Juliet is given some of the Friar Laurence's lines in order to more effectively make fun of Romeo's changeability in love. In the previous scenes, Romeo and Giulietta have bickered about his failure to pay child support, her unwillingness to allow Romeo access to their four daughters, along with the whereabouts of their youngest, Bianca, the only one currently in contact with her father. Romeo mistakes the name of their daughter Rosalinda as Rosalina, which causes Giulietta to pounce on Romeo, hurling Friar's words at him in a combination of Shakespearean and modern text:

\section{GIULIETTA}

The ice virgin. .. oh you'd fallen pretty hard.

ROMEO

Everyone was after her. . .

GIULIETTA

/Jesu Maria, what a deal of brine / Hath washed thy sallow cheeks for Rosaline. . ./ ROMEO

... I guess I was too. . .

GIULIETTA

/How much salt water thrown away in waste / To season love, that of it doth not taste. ... /

ROMEO

... with little success.

GIULIETTA 
/Lo, here upon thy cheek the stain doth sit / Of an old tear that is not washed off yet... I

\section{ROMEO}

But then you showed up.

GIULIETTA

To your misfortune.

ROMEO

Huh? (21)

The rhymes and rhythms of Giulietta's Shakespearean quotations contrast vividly with Romeo's prosaic recollections of his earlier infatuation, and transplanted from Friar Laurence to Giulietta, the words become even more teasing and ironic.

\section{Recognition of Plot and Theme}

These linguistic layerings provide much of the local effect and humor of the spin-offs, but larger patterns are also significant in the dramaturgy and effect of both plays, especially Romeo vs. Juliet, a topic I can only briefly touch on here but which is significant in understanding how textual sightings work in these Shakespeare appropriations. For in addition to the weaving of Shakespearean and modern text, another technique of recognition that Sipari and Urpelainen use is to juxtapose events in the Shakespearean play with simultaneous events in the modern story, a technique which in effect sets up a double time-line, both forwards and backwards, with the backwards line composed of motifs/lines from Shakespeare's play.

One of the more effective examples of this is the motif of banishment. In Scene 8 Romeo and Giulietta discuss the problems which destroyed their marriage: Giulietta blames Romeo for starting an affair with a rabid feminist called Pippa, while Romeo accuses Giulietta of having become cold, having literally turned her back on him. Into this sequence describing Romeo's departure from the family home are lines from Shakespeare's play about being banished: 


\section{ROMEO}

The end was so... the girls were away, you were away, my empty suitcase put on the bed... I wish you would've screamed at me, gotten furious, cleared the air... GIULIETTA

There was no more air to clear.

ROMEO

... nothing but paper... summons, seals, equitable division of property, contesting this and that... you get the house, I get the boot...

\section{GIULIETTA}

You carried that suitcase straight to Pippa's -

\section{ROMEO}

/Banishèd -/

GIULIETTA

- so it hadn't just been a one night stand.

\section{ROMEO}

/The damnèd use that word in hell. / Howling attends it--

\section{GIULIETTA}

It seemed like you had no idea what was going on. I remember that night... I was terrified...

\section{ROMEO}

Heaven is here

Where Juliet lives, and every cat and dog

And little mouse, every unworthy thing,

Live here in heaven and may look on her,

But Romeo may not ---

He is banishèd! (43-44)

Following banishment, an even more highly-developed juxtaposition of Shakespearean and modern plotting occurs in Scene 9, where Juliet's drinking of the poison is laid onto the modern story. In a fit of sentimentality and/or love (the play leaves this open), Romeo asks Giulietta if she will bury him, scatter his ashes "wherever you're allowed to scatter ashes. Into the wind" (49). Giulietta scoffs, saying "The wind will shift and I'll get you in my eye" (49). She accuses him of being theatrical, adolescent and asks why Loretta can't bury him. In fits and starts, Romeo indicates that 
Loretta is out of the picture, which at first Giulietta understands as meaning that she is dead. But then Romeo reveals that Loretta has moved (later it will be revealed that they fought over money and broke up). But in that moment Giulietta is furious that Romeo has deliberately misled her about Loretta's demise, or lack thereof, and she begins to utter Juliet's lines (3.2) at hearing that Romeo has murdered Tybalt while Romeo in the present needs to go the toilet again and asks on his way out whether she would like a digestif:

\section{GIULIETTA}

O serpent heart, hid with a flowering face!/

ROMEO

(Pointing to the entrance) I need to go...

GIULIETTA

/Dove-feather'd raven! wolvish-ravening lamb!. . ./

ROMEO

And don't you dare utter a word starting with pros---.

GIULIETTA

/Beautiful tyrant! fiend angelical!/

ROMEO

Do you want something? A digestif?

GIULIETTA

/Despised substance of divinest show!.../

ROMEO

Limoncello? Grappa?

GIULIETTA

/Did ever dragon keep so fair a cave?/ - Definitely not grappa. Limoncello. (54)

Romeo returns carrying two limoncellos, giving one to Giulietta, and it becomes the poison that Juliet must drink, which she does reciting much of the "come vial" speech from Shakespeare's 4.3. Romeo's limoncello, in turn, becomes the poison that he buys from the apothecary, and the scene ends with Romeo's lines “Come, cordial and not poison, go with me / To Juliet's grave; for there must I use thee" (56). Notice that here, 
too, Sipari/Urpelainen turn to passages containing oxymorons, perhaps indicating that they think audiences recognize oxymorons as typical of Romeo and Juliet.

All of these sequences recall Shakespeare's original plot, creating a complex two-part time scheme moving forwards and backwards at the same time: in the present, questioning whether Romeo and Juliet can get back together now, and in the past explaining how they managed to escape to Mantua. The possibility of reconciliation in the present is suggested in a sequence where Giulietta cries when she hears the truth that Romeo and his girlfriend Loretta have broken up due to a fight about money, and she realizes she wishes that Romeo could be happy. Romeo tries to comfort her by singing a song he used to sing to their daughters, "Tiritomba, tiritomba, tiritomba..." and they remember how his singing, and the way they danced to the song made all of them happy. They sing together, and according to the stage directions "perhaps improvise a dance” (61). In a performance I saw at the KOM theater in 2015, directed by Laura Jäntti, they almost kissed at the end of this sequence. Then in the parallel memory, Giulietta remembers that they had planned to commit double-suicide, jumping off handin-hand off the highest precipice they could find. But instead, they decided to escape to Mantua. Romeo remembers, "We had turned back from the brink of death, it seemed like all the happiness in the world was in us." Giulietta tries to dismiss this, saying "We were such kids," but Romeo insists on its beauty: "But such lovely kids. We kissed each other's fingers, one of us was the first to say 'to Mantua"' (62). At the end of this memory, Romeo does kiss Giulietta on the hand, and is about to ask something when there's an announcement that the trains have started to run, and the two must decide whether to part or risk having Romeo accompany Giulietta to their grand-daughter's christening. In layering plot details onto the modern story, Sipari and Urpelainen create a convincing comedy which both celebrates the source text while perhaps also gently 
questioning its tragic excesses. At the same time, they treat the audience to a second level of recognition and pleasure. Dramatically, the play follows familiar trajectories from both tragedy and comedy: in the Renaissance layer, the move is towards suicide which is then averted, while in the modern layer towards reconciliation, which in keeping with modern theatrical traditions is left open. Tragic catharsis is replaced with comic hope.

In a very different way, Juutinen uses the Romeo and Juliet story to examine the nature of tragic catharsis. ${ }^{13}$ He challenges his theatrical audience to see the humans behind his story of the fictional Juliet and her debts; he wants us to question what we feel at the end of a play like Romeo and Juliet. Rather than directly depicting the murders, Juutinen turns instead to a piece of meta-theater. The actress playing Juliet stops and directly addresses the audience, telling them that she cannot continue, for if she does, she'll have to describe what happened. But even this is a kind of ploy, because she then describes what "Juliet" did.

Ummm... I have to stop the performance for a moment.

We've come to the point where if I continue, I'll have to tell you that this 36-yearold mother, the one I've been playing, one of forty thousand Finns who've gotten into excessive debt, walked from here into her bedroom, her very own, very real bedroom. There she killed her very own, very real sleeping 37-year-old husband by shooting him in the head with a shotgun at close range.

After that we would have to go with her to her children's bedroom where she shoots her very own, very real, sweet six year old son, and her very own, very real, sweet eight year old daughter.

${ }^{13}$ On the nature of tragedy in Shakespeare's Romeo and Juliet, see especially Rist, Roberts, Leech and Smith. 
And finally we'd have to come back with her into her own bedroom, where she gets into bed next to her bloody husband. An hour later, she shoots the last liberating shot. (24-25).

Because she doesn't want to end the play with this story, the actress then says that they'll end the play with a different ending, a brief film called "Finland's Hope," which has a different morning scene, where Juliet is preparing breakfast for her two children, and everyone is smiling as they eat, and Raimo comes in and kisses Juliet on the cheek, then reads the newspaper as Juliet stands watching. This happy ending renders even more stark the real ending, both of Shakespeare's play and especially the real-life event. ${ }^{14}$ Juutinen's Juliet is very different from Shakespeare's, tellingly so: vulnerable to social demands and predatory bankers, experiencing such unspeakable shame (depression, even mental illness) that she is unable to discuss her financial situation with anyone, including her husband (in the real case, the husband apparently had no idea the family was in financial trouble, and the murders/suicide took place the day before their house was to be repossessed). If this spin-off provides tragic catharsis, it is of the bitterest possible kind, achieving its powerful effect precisely because of the thematic association with the love tragedy of Shakespeare's Romeo and Juliet.

In terms of the theoretical question I started with, these two Finnish rewritings clearly depend on recognition. They artfully weave Shakespearean quotations and echoes into their modern Finnish texts for varied effects, and the power of Shakespeare's language and story is acknowledged and put to use. Furthermore, they both attempt to reshape or extend our understanding of tragic catharsis, Juutinen by

\footnotetext{
${ }^{14}$ See also Smith, who speaking of the ends of tragedy, questions whether one feels pity/fear and pleasure simultaneously or in sequence (214). For an interesting contrast to how the early moderns might have thought of catharsis, see Rist.
} 
asking us to imagine how we would relate to the story if Romeo and Juliet were real people, while Sipari and Urpelainen turn tragedy into tragi-comedy, taking hints from Shakespeare and developing them into a story about adults in modern society.

Especially the linguistic quotations and echoes, but also the use of familiar motifs, may very well send audiences back to one of the Romeo and Juliet translations, or even to the English original, to compare and contrast with Shakespeare's version-in effect, creating a better audience for future spin-offs.

Both plays, I think, deserve a wider audience, but the politics and pleasures of global Shakespeare appropriation seem ultimately to be rather local, and these works have thus far not travelled very far. Why this might be so is subject for another paper.

\section{References}

Aaltonen, Sirkku. "La Perruque in a Rented Apartment: Rewriting Shakespeare in Finland.” Ilha do Desterro 36 (April 2008): 141-59.

Desmet, Christy. "Recognizing Shakespeare, Rethinking Fidelity: A Rhetoric and Ethics of Appropriation." In Huang and Rivlin, Shakespeare and the Ethics of Appropriation. New York: Palgrave Macmillan, 2014: 41-57.

Huang, Alexa and Elizabeth Rivlin. Shakespeare and the Ethics of Appropriation. New York: Palgrave Macmillan, 2014.

Hutcheon, Linda, with Siobhan O'Flynn. A Theory of Adaptation, $2^{\text {nd }}$ edition. London: Routledge, 2013.

Keinänen, Nely . "Canons and Heroes: The Reception of the Complete Works Translation Project in Finland, 2002-13." Multicultural Shakespeare volume 16.1 (2017): 109-25.

. What's 'global' about 'global Shakespeare'? The Case of Perttu Leppä's 8 päivää ensi-iltaan [8 Days to the Premiere]. Shakespeare (The Journal of the British Shakespeare Association), special issue on "Global Shakespeare," edited by Alex Huang. 9.3 (2013): 330-338.

“Suomalaisen Shakespeare-perinteen syntyvaiheista." In: Shakespeare

Suomessa, edited by N. Keinänen. Helsinki: WSOY, 2010: 15-33. 
Leech, Clifford. "The Moral Tragedy of Romeo and Juliet." Critical Essays on Shakespeare's Romeo and Juliet. Joseph A. Porter, ed. New York: G. K. Hall \& Co., 1997: 7-22.

Levenson, Jill. "Popular Adaptations for Theater." Cambridge Guide to the Worlds of Shakespeare, volume 2, Bruce R. Smith, ed. Cambridge: Cambridge UP, 2016: 1297-1305.

Orkin, Martin. "Local, Global and 'Glocal'." Cambridge Guide to the Worlds of Shakespeare, volume 2, Bruce R. Smith, ed. Cambridge: Cambridge UP, 2016: 1070-1077.

Rissanen, Matti. ”Ollako vai eikö olla? Kenen käännös? Kas siinä pulma” [To be or not to be? Whose Translation? That is the Question]. Helsinki: Research Unit for Variation, Contacts and Change in English (Varieng), University of Helsinki, 2013. electronic. <: https://variblog.wordpress.com/2013/12/20/ollako-vai-eikoolla-kenen-kaannos-kas-siina-pulma/ > .

Rist, Thomas. "Catharsis as 'purgation' in Shakespearean drama." Shakespearean Sensations: Experiencing Literature in Early Modern England. Katharine A. Craik and Tanya Pollards, eds. Cambridge: Cambridge UP, 2013. 138-53.

Roberts, Sasha. "Reading Shakespeare's Tragedies of Love: Romeo and Juliet, Othello, and Antony and Cleopatra in Early Modern England." A Companion to Shakespeare's Works, Volume 1, The Tragedies. Richard Dutton and Jean E. Howard, eds. Malden: MA: Blackwell, Publishing, 2003. 108-33.

Sanders, Julie. Adaptation and Appropriation. London: Routledge, 2006. Scott-Douglass, Amy. "Shakespeare Spin-offs." Cambridge Guide to the Worlds of Shakespeare, volume 2, Bruce R. Smith, ed. Cambridge: Cambridge UP, 2016: 1281-90.

Smith, Bruce. "Afterward: Senses of an Ending." Shakespearean Sensations: Experiencing Literature in Early Modern England. Katharine A. Craik and Tanya Pollards, eds. Cambridge: Cambridge UP, 2013. 208-17. 